\title{
Performance Analysis of OFDMA and SC-FDMA
}

\author{
AL-Rawi, Muhanned \\ University of Ibb, Yemen \\ E-mail: muhrawi@yahoo.com
}

\begin{abstract}
The main challenge in any high-speed digital communication system is how to maximize the data rate with minimizing the bit error rate. Several techniques have been developed to achieve this point. Some of these techniques are orthogonal frequency division multiplexing (OFDM), single-carrier frequency domain equalization (SC-FDE), orthogonal frequency division multiple access (OFDMA), and single-carrier frequency division multiple access (SC-FDMA). These four techniques are described briefly in this paper. Also, the paper measures the performances of OFDMA and SC-FDMA systems over international telecommunication union (ITU) vehicular-A channel using minimum mean square error (MMSE) equalization. Simulation results show that the performances with interleaved mapping outperform that with localized mapping. Also, the performances with quadrature phase shift keying(QPSK) are better than that with 16-ary quadrature amplitude modulation (16QAM). In addition, the performance of SC-FDMA is better than that of OFDMA, when QPSK is used, but the latter is little bit better than that of SC-FDMA when 16QAM is used
\end{abstract}

Key words: OFDM; SC-FDE; OFDMA; SC-FDMA

\section{Introduction}

Multi-carrier transmission techniques are used in modern wireless mobile systems to provide virtually error-free high bit rates. In order to achieve this purpose, the use of multi-carrier modulation (MCM) has become a popular option. MCM is based on the idea of dividing the transmitted data stream into several symbol streams, with a much lower symbol rate, which are used to modulate several sub-carriers. MCM presents a relative immunity to multipath fading and has a lesser susceptibility to interference caused by impulse noise than that presented by single-carrier systems. Additionally, it demonstrates enhanced immunity to interference.

The most prominent example of MCM transmission is orthogonal frequency division multiplexing (OFDM) [1-3]. In this technique, a large number of orthogonal sub-carriers are used to transmit information from several parallel streams modulated with a digital modulation scheme. If these data streams belong to different terminals or users, OFDM becomes orthogonal frequency division multiple access (OFDMA) [3-6] in which different data signals are transmitted through a common physical media that is divided into frequency resources units. Both OFDM and OFDMA suffer from power distortion that may be particularly troublesome in uplink transmissions where excessive complexity in user terminal is an issue. With the purpose of overcoming that limitation, single-carrier frequency division multiple access (SCFDMA) [3, 4, 7-9] was chosen as the uplink multiple access scheme due to its lower power distortion. The
SC-FDMA uses a modulation scheme known as singlecarrier frequency domain equalization (SC-FDE) $[1,3]$. The SC-FDE is based on OFDM but uses only a single carrier.

\section{OFDM System Model}

Fig. 1 shows the block diagram of OFDM system model [1,3]. At the OFDM transmitter, the input binary data is mapped to constellations in frequency domain using typically, quadrature amplitude modulation (QAM) or phase shift keying (PSK). Then, the data is converted from serial to parallel $(\mathrm{S} / \mathrm{P})$. After that, the data is converted to a time domain signal using an inverse fast Fourier transform (IFFT).

Afterwards, the last part of the signal is appended to the beginning of the signal, known as the cyclic prefix $(\mathrm{CP})$, in part to fight intersymbol interference (ISI) and also to convert the signal's linear convolution with the channel impulse response to a circular convolution. Lastly, the data is converted from parallel to serial and sent through multipath communication channel with additive white Gaussian noise (AWGN). At OFDM receiver, the reverse operation of the OFDM transmitter is achieved. One important feature of OFDM receiver is its ability to equalize in frequency domain. There are many different ways of equalizing, two of which are the zero-forcing (ZF) equalizer and the minimum mean square error (MMSE) equalizer. While they both correctly recover the phase of the signal, the $\mathrm{ZF}$ equalizer causes noise enhancement and the 
MMSE equalizer causes time distortion in the signal. One benefit of equalization using any frequency domain technique, is that applying it is simple, an element-wise multiplication in the frequency domain.

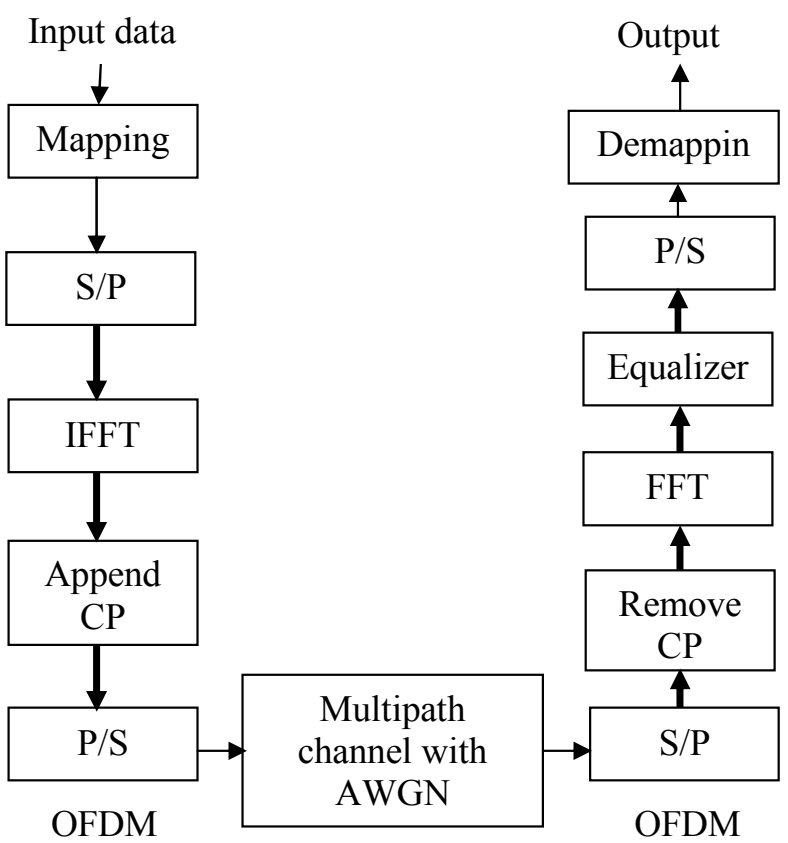

Fig. 1. OFDM system model

\section{SC-FDE System Model}

Fig. 2 shows the block diagram of SC-FDE system model [1, 3]. SC-FDE is a variation of OFDM, a modulation scheme that contains all the same blocks but moves the IFFT from the transmitter to the receiver. The difference between this system and OFDM is that the constellation mapping takes place in time domain, and the $\mathrm{CP}$ is the last time samples appended to the beginning of the signal. Equivalently, an SC-FDE symbol is a group of $N+\Delta$ modulated (QAM, PSK) sub-symbols, where $\mathrm{N}$ is the length of the FFT/IFFT used in the receiver, and $\Delta$ is the length of the cyclic prefix. This makes for a very simple transmitter. By moving the IFFT to the receiver, equalization is done with a simple multiplication in frequency domain like in an OFDM receiver.

\section{OFDMA System Model}

The OFDMA system model is shown in Fig. 3 [3,4]. OFDMA is very similar to OFDM in function, with the main difference being that instead of being allocated all of the available subcarriers, the base station allocates a subset of carriers to each user in order to accommodate multiple transmissions simultaneously.

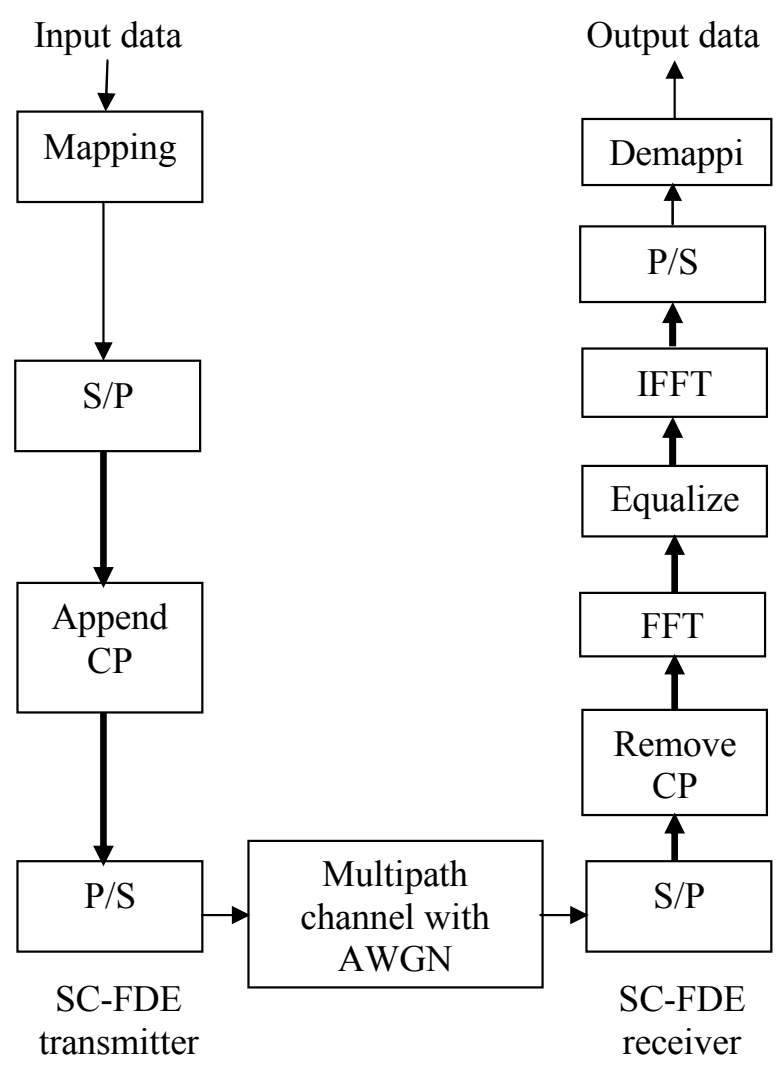

Fig. 2. SC-FDE system model

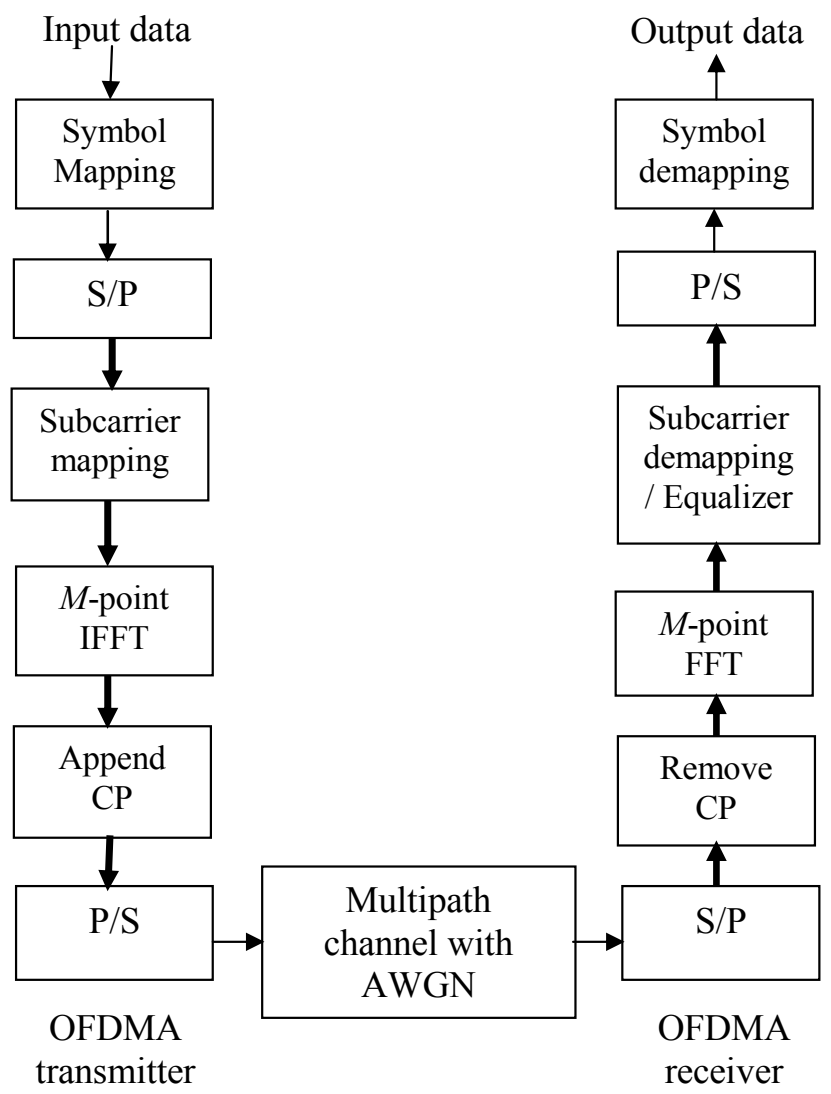

Fig. 3. OFDMA system model

A problem with OFDMA as compared to OFDM is its high sensitivity to frequency offset. In OFDM since 
all the frequencies of the subcarriers were generated by one transmitter, maintaining orthogonality of the subcarriers is relatively easy. In OFDMA, since many users transmit simultaneously, each with their own estimates of the subcarrier frequencies, a frequency offset is inevitable and multiple access interference occurs as users' power leaks into subcarriers bands.

\section{SC-FDMA System Model}

The SC-FDMA system model is shown in Fig. 4 [3, 4]. SC-FDMA is the multiple access version of SC-FDE, which is similar to OFDM, in that they both perform channel estimation and equalization in the frequency domain. Multiple access is achieved in frequency domain in SC-FDMA. Thus to transition from SCFDE to SC-FDMA requires division frequency amongst frequencies. This is achieved by the first performing an $N$-point FFT on the output of the symbol mapper, and mapping the output of the FFT to $\mathrm{N}$ of M subcarriers, with $M=Q N$ where $Q$ is an integer called the bandwidth expansion factor of the symbol, which is effectively the number of simultaneous users that the system supports. Afterwards the M-point IFFT converts the signal back into time domain. Likewise in the receiver, only $\mathrm{N}$ of the $\mathrm{M}$ frequencies of the output of the FFT correspond to this user, so those $\mathrm{N}$ values are equalized and an $N$-point IFFT is performed to get the original signal back.

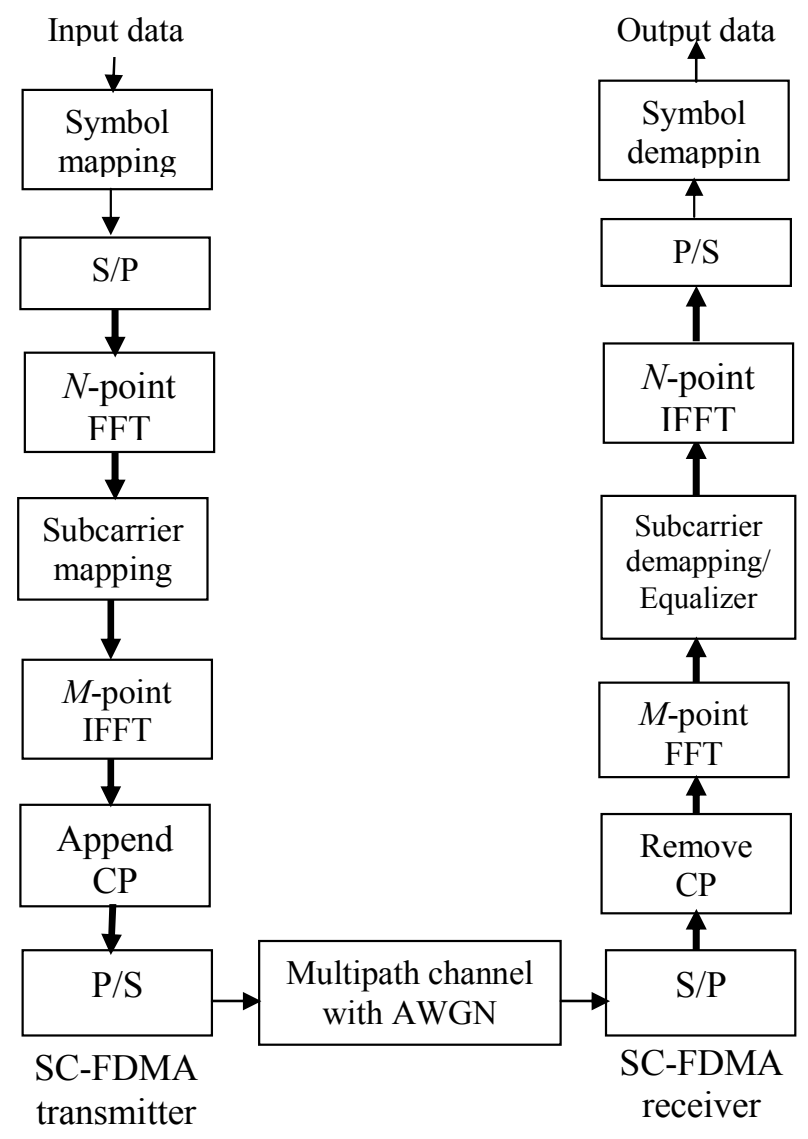

Fig. 4. SC-FDMA system model
An important consideration to be made is how the $\mathrm{N}$ points of the signal are mapped to the $M$ subcarriers of the system. Two main strategies exist: use $\mathrm{N}$ adjacent subcarriers, called localized FDMA (LFDMA) or distribute the $N$ values across the $M$ subcarriers using every Q-th subcarrier, called interleaved FDMA (IFDMA). Also, these two strategies are applicable for OFDMA. The disadvantage of IFDMA is that it is very sensitive to frequency offset like OFDMA since different users take adjacent subcarriers. LFDMA, however, is much less affected by this because it only has at most two adjacent users.

\section{Simulation Results}

Computer simulation tests are carried out on OFDMA system model shown in Fig. 3, and SC-FDMA system model shown in Fig. 4. The performances of OFDMA and SC-FDMA systems are measured, over multipath channel with AWGN, in terms of bit error rate $(\mathrm{BER})$ versus signal to noise ratio $(\mathrm{Eb} / \mathrm{No})$. The type of channel used is ITU vehicular-A channel. Two modulation formats are used, QPSK, and 16QAM. The type of equalizer used is MMSE equalizer. Two mapping strategies are involved in the simulation, localized mapping and interleaved mapping.

Fig. 5 and Fig. 6 show the performances of OFDMA and SC-FDMA systems respectively. It can be concluded that the performances of both systems with interleaved mapping are better than that with localized mapping for both modulation formats. Also, the performances with QPSK are better than that with 16QAM. In addition, by comparing between Fig. 5 and Fig. 6, it can be seen that the performance of SC-FDMA is better than that of OFDMA for both mapping strategies with QPSK modulation format. But, the performance of OFDMA is little bit better than that of SC-FDMA for both mapping strategies with 16QAM modulation format.

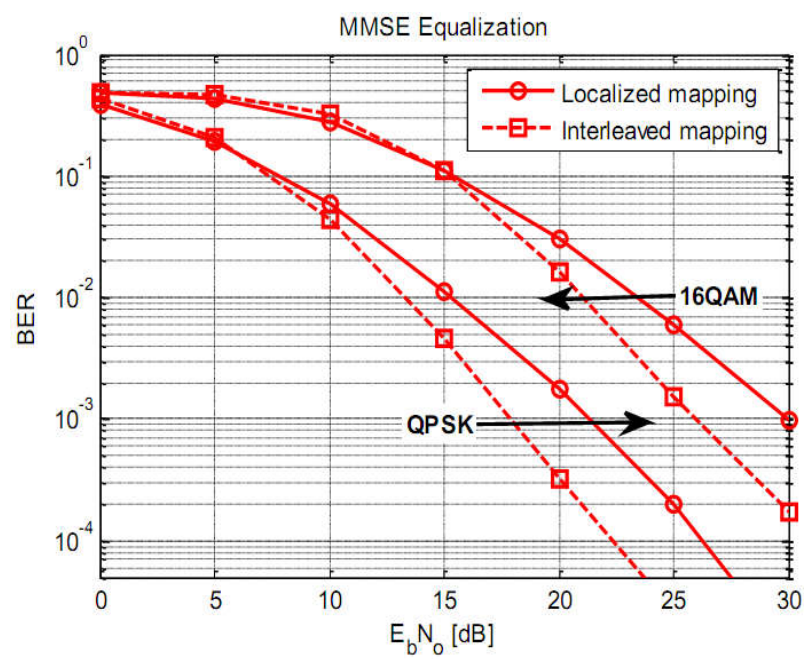

Fig. 5. Error rate performance of OFDMA 


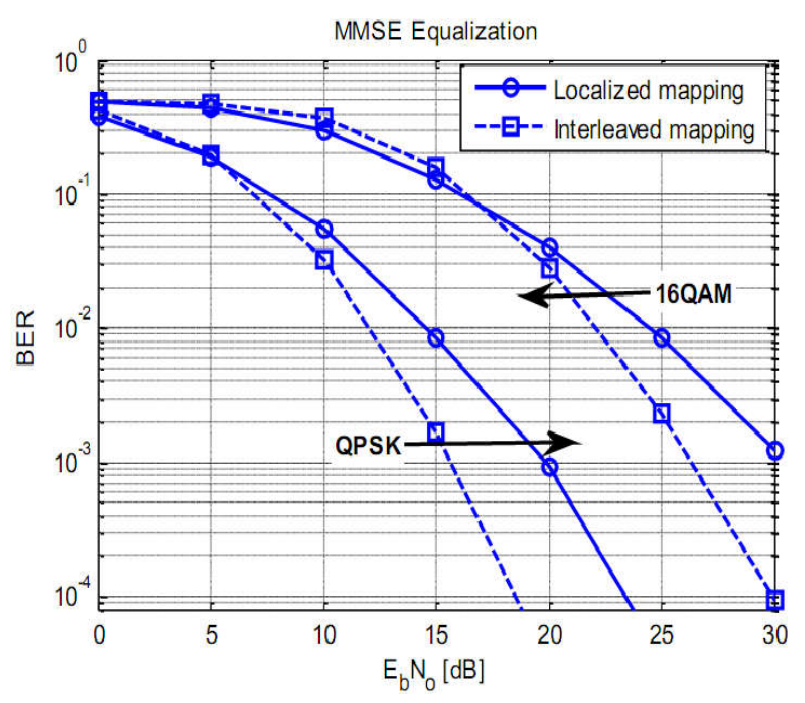

Fig. 6. Error rate performance of SC-FDMA

\section{Conclusion}

OFDM, SC-FDE, OFDMA, and SC-FDMA systems were presented in this paper. The performances of OFDMA and SC-FDMA systems were measured over ITU vehicular-A channel using localized and interleaved mapping strategies with QPSK and 16QAM modulation formats, and MMSE equalizer. From the measuring results, it can be concluded that the performances with interleaved mapping are better than that with localized mapping. Also, the performances with QPSK are better than that with 16QAM.

Furthermore, the performance of SC-FDMA is better than that of OFDMA in case of QPSK modulation format, but the performance of OFDMA is little bit better than that of SC-FDMA in case of 16QAM modulation format.

\section{References}

[1] Li J., Du Y. and Liu Y. (2006) Comparison of Spectral Efficiency for OFDM and SC-FDE under IEEE 802.16 Scenario, Proceedings of the 11th IEEE Symposium on Computers and Communications (ISCC'06). DOI: $10.1109 /$ iscc. 2006.52

[2] Weinstein S. B. (2009) The History of Orthogonal Frequency Division Multiplexing [History of Communications], IEEE Communications Magazine, Vol. 47, Is. 11. DOI: $10.1109 /$ mcom.2009.5307460

[3] Soltani N. (2009) Comparison of Single-Carrier FDMA vs. OFDMA as 3GPP Long-Term Evolution Uplink, EE359 Project, Stanford University, USA.

[4] Myung H. G., Lim J. and Goodman D. J. (2010) Single Carrier FDMA for Uplink Wireless Transmission, IEEE Vehicular Technology Magazine, Vol. 1, No. 3. DOI: $10.1109 /$ mvt.2006.307304

[5] Ciochina C. and Sari H. (2010) A review of OFDMA and single-carrier FDMA, Proceedings of European Wireless Conference. DOI: 10.1109/ew.2010.5483464
[6] Khan A. S., Fauzi A. H., R. Thangaveloo R., Julahi A. A. and Tarmizi S. (2015) A Review on Orthogonal Frequency Division Multiple Access (OFDMA) in Broadband Wireless Access, International Journal of Advanced Engineering Research and Applications, Vol. 1, No. 8, pp. 320-336.

[7] Mewada R. and Sharma A. (2014) Review Analysis for Implementation of SC-FDMA over WiMAX Broadband Networks, International Journal of Engineering Trends and Technology, Vol. 11, No. 10, pp. 510-515. DOI: 10.14445/22315381/ijett-v11p300

[8] Singh N. and Mittal R. (2014) Review on Performance Analysis of Detection of Single Carrier FDMA, International Journal of Engineering Research 83 Technology, Vol.3, Is. 8., pp. 307-309.

[9] Lande S. B., Gawali J. D. and Kharad S. M. (2016) Performance Evolution of SC-FDMA for Mobile Communication System, International Journal of Future Generation Communication and Networking, Vol.9, No.2, DOI: 10.14257/ijfgen.2016.9.2.24

\section{Аналіз ефективності частотного муль- типлексування OFDMA і SC-FDMA}

\section{Муханнед Аль-Раві}

Основна проблема в будь-якій високошвидкісній цифровій системі зв'язку полягає в тому, як максимізувати швидкість передачі даних, зводячи до мінімуму частоту помилок в бітах. Для досягнення цієї мети існуе кілька методів, до яких належить мультиплексування з ортогональним частотним розділенням (OFDM), вирівнювання частотної області з однією несучою (SC$\mathrm{FDE}$ ), множинний доступ з ортогональним частотним розділенням (OFDMA) і множинний доступ 3 частотним поділом з однією несучою (SC-FDMA). У цій статті проведена оцінка продуктивності систем OFDMA і SCFDMA по каналу "vehicular-A"міжнародного телекомунікаційного союзу (ITU) з використанням вирівнювання середньої квадратичної помилки (MMSE). Результати моделювання показують, що характеристики з почерговим мапінгом перевершують показники з локалізованим мапінгом. Крім того, характеристики з квадратурною фазовою маніпуляцією (QPSK) кращі, ніж у разі 16кратної квадратурної амплітудної модуляції (16QAM). Продуктивність SC-FDMA краща, ніж продуктивність OFDMA з використанням QPSK, яка в свою чергу трохи краща за продуктивність SC-FDMA з 16QAM.

Ключові слова: OFDM; SC-FDE; OFDMA; SC-FDMA

\section{Анализ эффективности частотного мультиплексирования OFDMA и SC- FDMA}

\section{Муханнед Аль-Рави}

Основная проблема в любой высокоскоростной цифровой системе связи заключается в том, как максимизировать скорость передачи данных, сводя к минимуму частоту ошибок в битах. Для достижения этой цели было разработано несколько методов, в том числе мультиплексирование с ортогональным частотным разделением (OFDM), выравнивание частотной области с 
одной несущей (SC-FDE), множественный доступ с ортогональным частотным разделением (OFDMA) и множественный доступ с частотным разделением с одной несущей (SC-FDMA). В этой статье проведена оценка производительности систем OFDMA и SC-FDMA по каналу "vehicular-A" международного телекоммуникационного союза (ITU) с использованием выравнивания средней квадратичной ошибки (MMSE). Результаты моделирования показывают, что характеристики с чередующимся "маппингом" превосходят показатели с локализованным "маппингом". Кроме того, характеристики с квадратурной фазовой манипуляцией (QPSK) лучше, чем при 16-кратной квадратурной амплитудной модуляции (16QAM). Производительность SC-FDMA лучше, чем производительность OFDMA с использованием QPSK, которая в свою очередь немного лучше, чем производительность SC-FDMA с 16QAM.

Ключевие слова: OFDM; SC-FDE; OFDMA; SCFDMA 